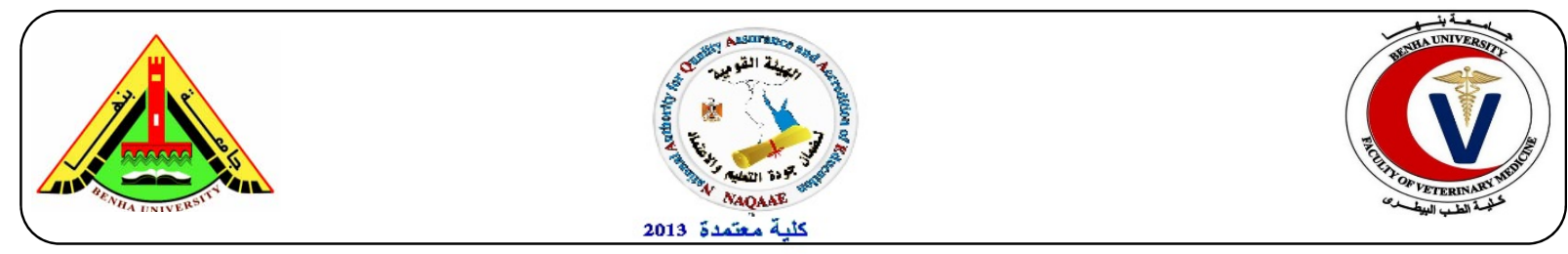

\title{
Efficiency of some essential oils in Control of Methicillin Resistant Staphylococcus Aureus (MRSA) in Minced Beef
}

\author{
Amani, M. Salem ${ }^{1}$; Zakaria, E.M. ${ }^{2}$; Abd EI -Raheem, K.A. ${ }^{1}$ \\ ${ }^{1}$ Faculty of Veterinary Medicine, Benha University, Egypt \\ ${ }^{2}$ Animal Health Research Institute, Dokki, Egypt
}

\section{A B S T R A C T}

In this study, the antibacterial effect of Cinnamon, Thyme and Lemongrass essential oils against Methicillin Resistant Staphylococcus aureus (MRSA) artificially inoculated into refrigerated minced beef was investigated. Sensory analysis indicated significant advantages in using these oils in refrigerated minced beef. Also, results indicated that the MRSA counts decreased as the concentration of the oil increases since the concentration $(1.5 \%)$ gives the best effectiveness. In addition, a highly significant differences $(P<0.05)$ as a result of oil treatments were noticed. The antibacterial activities of the added essential oils followed the order, Cinnamon $>$ Thyme $>$ Lemongrass oil. The shelf life of the treated samples was extended than control ones. In conclusion, these oils especially cinnamon one can be useful for commercial application as potential food preservatives and anti- MRSA agents in food.

Key words: MRSA, Essential oils, minced beef, Antimicrobial.

(http://www.bvmj.bu.edu.eg)

(BVMJ-32(1): 177-183, 2017)

\section{INDRODUCTION}

Meat is a nutritious protein- rich food which is highly perishable and has a short- life unless preservation methods are used (Olaoye and Onilude, 2010). However, it gets easily contaminated by pathogenic microorganisms present in animal prior to slaughter. It is therefore important to make meat safe for consumers in terms of stability, transportation and storage (Lambert et al., 1991). Food that contaminated with antibiotic resistant bacteria such as MRSA can be a major threat to the public health. The antibiotic resistance determinants can be transferred to other bacteria of human clinical significance (Threlfall et al., 2000). Also the most of the nosocomial Staphylococcus aureus infections are caused by Methicillin Resistant Staphylococcus aureus (MRSA) strains and have become a widely recognized cause of morbidity and mortality throughout the world (Pesavento et al., 2007). Although several synthetic food additives have been widely used in the meat industry to extend shelf life and delay or inhibit the growth of pathogenic microorganisms, the trend is to decrease their use because of the growing concern about such chemical additives. Essential oils are regarded as natural alternatives of chemical preservatives and their use in food meets the demands of consumers for mildly processed or natural products, since in modern food industries, mild processes are applied in order to obtain safe products which have a natural or "green" image (Burt, 2004). Among the greater variety of essential oils lemongrass, thyme and cinnamon oils have gained greater acceptance among food technologists due to their better sensory evaluation and antimicrobial properties (Fisher and Phillips, 2006). Cinnamon oil was reported to consist of many components such as cinnamaldehyde, eugenol, and linalool. Cinnamaldehyde was the predominant active compound found in cinnamon oil. Cinnamaldehyde leads to inhibition of N- 3oxohexanoyl-Lhomoserine lactone (3- oxo-C6HSL) and AI-2 and has the potential to affect bacterial QS regulated processes (Niu et al., 2006). Thyme oil is commonly used in foods mainly for its flavor and aroma. Also thymol which is found in thyme oil, it is active against E. coli and $S$. aureus and spoilage flora in meat products, completely stops the growth of fungi at low concentrations and inhibits the aflatoxin production, so it has a role as pharmaceutical and preservative (Soliman and badeaa, 2002). Lemongrass oil is composed of three main components, the alpha and beta-citral components 
which elicit antibacterial action on Gram-positive and Gram-negative organisms, while the third component is mycrene which provided enhanced activities when mixed with either of the two main previously identified components (Onawunmi et al., 1984).

Therefore, the main target of this work was to investigate the antibacterial activity of some essential oils especially Cinnamon, Thyme and Lemongrass oils against MRSA strains in minced beef.

\section{MATERIAL AND METHODS}

\subsection{Preparation of essential oils:}

The ready-made herbal oils of Cinnamon (Cinnamon Zeylanicum), Thyme (Thymus vulgaris) and Lemongrass (Cymbopogon citratus) (CAP PHARM) in different concentrations were prepared.

\subsection{Preparation of bacterial strain:}

Methicillin resistant Staph. aureus strain was obtained from Bacteriology Department, Animal Health Research Institute, Dokki, Giza, Egypt, then prepared at the recommended infective dose $\left(>10^{5}\right.$ CFU /g) (Stewart et al., 2003).

\subsection{Experimental application:}

A grand total of $3 \mathrm{~kg}$ of fresh minced beef used in this study was divided into 30 samples (100 gm of each). Each sample was inoculated with $S$. aureus $\left(10^{6} \mathrm{CFU} / \mathrm{g}\right)$ Initial load of MRSA was detected before addition of essential oils. Essential oils of Cinnamon, Thyme and Lemongrass $(\% \mathrm{v} / \mathrm{g})$ were added to the samples to achieve final concentrations of $(0.5),(1)$ and $(1.5 \%)$. Phosphate buffer saline was used for treatment of control (untreated) samples. Each sample was packed in polyethylene bag, labeled and stored at $4{ }^{\circ} \mathrm{C}$. The experiment was conducted in triplicate.

\subsection{Sensory examinations: according to Pearson and Tauber (1984) and Patsias et al. (2006).}

\subsection{Determination of MRSA count: according to Heuvelink et al. (2009).}

\subsection{Statistical analysis: according to Feldman et al. (2003).}

\section{RESULTS}

Results in table (1) showed that in case of using Cinnamon oil at concentration of $0.5 \%, 1 \%$ and $1.5 \%$ the scores of overall acceptability were 7,6 , $5,4,3 \& 8,7,6,5,4$ and 9, 8, 7, 6, 5 at 3 hrs., $1^{\text {st }}$, $2^{\text {nd }}, 3^{\text {rd }}$ and $4^{\text {th }}$ day of the storage period respectively. While in case of using Thyme oil at concentration of $0.5 \%, 1 \%$ and $1.5 \%$ the scores of sensory evaluation were $7,6,5,4,3 \& 8,7,6,5,4$ and $8,7,7,6,4$ after $3 \mathrm{hrs} ., 1^{\text {st }}, 2^{\text {nd }}, 3^{\text {rd }}$ and $4^{\text {th }}$ day of the storage period respectively. While in case of using Lemongrass oil at concentration of $0.5 \%, 1 \%$ and $1.5 \%$ the scores of sensory evaluation were 7 , $6,5,4,3 \& 7,7,6,5,4$ and 8, 7, 6, 5, 4 at 3hrs., $1^{\text {st }}$, $2^{\text {nd }}, 3^{\text {rd }}$ and $4^{\text {th }}$ day of the storage period respectively. Comparing to the scores of sensory evaluation of control sample were $6,4,3,2,1$ at $3 \mathrm{hrs}, 1^{\text {st }}, 2^{\text {nd }}, 3^{\text {rd }}$ and $4^{\text {th }}$ day of the storage period respectively.

It is evident from the results that obtained in Table (2) that the initial count of MRSA in minced beef samples after inoculation (at zero time) was $10.28(\log \mathrm{CFU} / \mathrm{g})$. The inhibition of MRSA is related to the concentration of essential oils, since they declined when increasing the concentration of oil. In case of treated minced beef samples with Cinnamon oil in concentration of $(0.5 \%),(1 \%)$ and $(1.5 \%)$ the mean values of MRSA count (log $\mathrm{CFU} / \mathrm{g})$ were decreased to $8.27 \pm 5.55,7.65 \pm 5.55$, $6.77 \pm 3.89,5.92 \pm 3.12,4.55 \pm 2.97 \& 7.33 \pm 5.05$ $6.42 \pm 3.76,5.83 \pm 3.65,4.73 \pm 2.89,3.97 \pm 2.35$ and $6.55 \pm 4.22,4.95 \pm 2.58,3.87 \pm 2.81,2.95 \pm$ $2.03,2.68 \pm 1.14$ at $3 \mathrm{hrs}, 1^{\text {st }}, 2^{\text {nd }}, 3^{\text {rd }}$ and $4^{\text {th }}$ day of the storage period $\left(4 \pm 1^{\circ} \mathrm{C}\right)$, respectively. While in treated minced beef samples with Thyme oil in concentration of $(0.5 \%),(1 \%)$ and $(1.5 \%)$ the mean values of MRSA count (log $\mathrm{CFU} / \mathrm{g})$ were decreased to $8.68 \pm 5.20,8.32 \pm 5.80,7.38 \pm 5.22$, $6.63 \pm 4.99,6.22 \pm 4.01 \& 7.83 \pm 4.99,6.78 \pm 4.85$, $6.42 \pm 4.77,5.56 \pm 3.82,5.14 \pm 3.11$ and $6.87 \pm$ $3.67,5.88 \pm 3.22,4.76 \pm 2.95,4.17 \pm 2.83,3.75 \pm$ 1.88 at $3 \mathrm{hrs} ., 1^{\text {st }}, 2^{\text {nd }}, 3^{\text {rd }}$ and $4^{\text {th }}$ day of the storage period $\left(4 \pm 1^{\circ} \mathrm{C}\right)$, respectively. Furthermore, in treated minced beef samples with Lemongrass oil in concentration of $(0.5 \%),(1 \%)$ and $(1.5 \%)$ the mean values of MRSA count $(\log \mathrm{CFU} / \mathrm{g})$ were reduced to $8.78 \pm 6.16,8.24 \pm 5.55,7.81 \pm 5.05$, $7.41 \pm 4.85,6.57 \pm 4.23 \& 7.92 \pm 5.88,7.29 \pm 4.88$, $6.75 \pm 3.77,6.23 \pm 3.55,5.81 \pm 3.00$ and $7.22 \pm$ $4.01,6.91 \pm 3.78,6.19 \pm 3.56,5.79 \pm 3.22,4.34 \pm$ 2.89 at $3 \mathrm{hrs} ., 1^{\text {st }}, 2^{\text {nd }}, 3^{\text {rd }}$ and $4^{\text {th }}$ day of the storage period $\left(4 \pm 1^{\circ} \mathrm{C}\right)$, respectively. Comparing to mean values of MRSA count (log CFU/g) in control minced beef samples were $8.86 \pm 6.56,8.95 \pm 6.22$, $9.65 \pm 7.75,9.93 \pm 8.07$ and $10.32 \pm 8.54$ at $3 \mathrm{hrs}$., $1^{\text {st }}, 2^{\text {nd }}, 3^{\text {rd }}$ and $4^{\text {th }}$ day of storage period $\left(4 \pm 1^{\circ} \mathrm{C}\right)$, respectively.

As shown in Table (3) the reduction \% of MRSA counts artificially inoculated into minced beef samples treated with Cinnamon oil (0.5\%) increased to $19.55 \%, 25.58 \%, 34.14 \%, 42.41 \%$, $55.47 \%$, in concentration of $(1 \%)$ increased to $28.69 \%, 37.55 \%, 53.29 \%, 53.99 \%, 61.38 \%$ and in concentration of (1.5\%) increased to $36.28 \%$, 
$51.58 \%, 62.23 \%, 71.3 \%, 73.92 \%$ at $3 \mathrm{hrs} ., 1^{\text {st }}, 2^{\text {nd }}$, $3^{\text {rd }}$ and $4^{\text {th }}$ day of the storage period $\left(4 \pm 1^{\circ} \mathrm{C}\right)$, respectively. While the reduction \% of MRSA counts artificially inoculated into minced beef samples treated with Thyme oil $(0.5 \%)$ increased to $15.56 \%, 19.10 \%, 23.83 \%, 35.51 \%, 39.49 \%$, in concentration of $(1 \%)$ increased to $23.83 \%$, $34.04 \%, 37.55 \%, 45.91 \%, 50.00 \%$ and in concentration of (1.5\%) increased to $33.17 \%$, $42.80 \%, 53.69 \%, 59.43 \%, 63.52 \%$ at $3 \mathrm{hrs} ., 1^{\text {st }}$, $2^{\text {nd }}, 3^{\text {rd }}$ and $4^{\text {th }}$ day of the storage period $\left(4 \pm 1^{\circ} \mathrm{C}\right)$, respectively. And the reduction \% of MRSA counts artificially inoculated into minced beef samples treated with Lemongrass oil $(0.5 \%)$ increased to $13.72 \%, 19.85 \%, 24.03 \%, 27.92 \%, 34.34 \%$, in concentration of (1\%) increased to $22.95 \%, 22.96$ $\%, 34.34 \%, 39.40 \%, 43.48 \%$ and in concentration of $(1.5 \%)$ increased to $22.96 \%, 32.78 \%, 39.79 \%$, $43.77 \%, 57.79 \%$ at $3 \mathrm{hrs} ., 1^{\text {st, }} 2^{\text {nd }}, 3^{\text {rd }}$ and $4^{\text {th }}$ day of the storage period $\left(4 \pm 1^{\circ} \mathrm{C}\right)$, respectively. All results of oil treatments showed significant growth inhibition of MRSA organism in minced beef samples $(P<0.05)$.

Table (1): Sensory evaluation of control and treated minced beef samples experimentally inoculated with MRSA organism during cold storage at $4{ }^{\circ} \mathrm{C}$.

\begin{tabular}{|c|c|c|c|c|c|c|}
\hline \multicolumn{2}{|c|}{$\begin{array}{r}\text { Time } \\
\text { Oil concentrations }\end{array}$} & $3 \mathrm{hrs}$ & $1^{\text {st }}$ day & $2^{\text {nd }}$ day & $3^{\text {rd }}$ day & $4^{\text {th }}$ day \\
\hline \multirow[t]{2}{*}{ control } & & 6 & 4 & 3 & 2 & 1 \\
\hline & $0.5 \%$ & 7 & 6 & 5 & 4 & 3 \\
\hline \multirow[t]{3}{*}{ Cinnamon oil } & $1 \%$ & 8 & 7 & 6 & 5 & 4 \\
\hline & $1.5 \%$ & 9 & 8 & 7 & 6 & 5 \\
\hline & $0.5 \%$ & 7 & 6 & 5 & 4 & 3 \\
\hline \multirow[t]{3}{*}{ Thyme oil } & $1 \%$ & 8 & 7 & 6 & 5 & 4 \\
\hline & $1.5 \%$ & 8 & 7 & 7 & 6 & 4 \\
\hline & $0.5 \%$ & 7 & 6 & 5 & 4 & 3 \\
\hline \multirow[t]{2}{*}{ Lemongrass oil } & $1 \%$ & 7 & 7 & 6 & 5 & 4 \\
\hline & $1.5 \%$ & 8 & 7 & 6 & 5 & 4 \\
\hline
\end{tabular}

Score system for sensory evaluation: 9: Excellent. 6: Good. 3: Poor. 8: Very very good. 5: Medium. 2: Very poor. 7: Very good. 4: Fair. 1: Very very poor

Table (2): Antimicrobial effect of different concentrations of Cinnamon, Thyme, Lemongrass oils against MRSA organism $(\log \mathrm{CFU} / \mathrm{g})$ artificially inoculated into minced beef samples during cold storage at $4{ }^{\circ} \mathrm{C}$.

\begin{tabular}{lllllll}
\hline Groups & Oil & 3hrs & $1^{\text {st }}$ day & $2^{\text {nd }}$ day & $3^{\text {rd }}$ day & $4^{\text {th }}$ day \\
& concentration & & & & & \\
\hline control & - & $8.86 \pm 6.56^{\mathrm{a}}$ & $8.95 \pm 6.22^{\mathrm{a}}$ & $9.65 \pm 7.75^{\mathrm{a}}$ & $9.93 \pm 8.07^{\mathrm{a}}$ & $10.32 \pm 8.54^{\mathrm{a}}$ \\
Cinnamon oil & $0.5 \%$ & $8.27 \pm 5.55^{\mathrm{a}}$ & $7.65 \pm 5.55^{\mathrm{ac}}$ & $6.77 \pm 3.89^{\mathrm{b}}$ & $5.92 \pm 3.12^{\mathrm{b}}$ & $4.55 \pm 2.97^{\mathrm{b}}$ \\
& $1 \%$ & $7.33 \pm 5.05^{\mathrm{b}}$ & $6.42 \pm 3.76^{\mathrm{ab}}$ & $5.83 \pm 3.65^{\mathrm{b}}$ & $4.73 \pm 2.89^{\mathrm{b}}$ & $3.97 \pm 2.35^{\mathrm{b}}$ \\
& $1.5 \%$ & $6.55 \pm 4.22^{\mathrm{c}}$ & $4.95 \pm 2.58^{\mathrm{bc}}$ & $3.87 \pm 2.81^{\mathrm{c}}$ & $2.95 \pm 2.03^{\mathrm{b}}$ & $2.68 \pm 1.14^{\mathrm{b}}$ \\
Thyme oil & $0.5 \%$ & $8.68 \pm 5.20^{\mathrm{a}}$ & $8.32 \pm 5.80^{\mathrm{a}}$ & $7.38 \pm 5.22^{\mathrm{b}}$ & $6.63 \pm 4.99^{\mathrm{b}}$ & $6.22 \pm 4.01^{\mathrm{b}}$ \\
& $1 \%$ & $7.83 \pm 4.99^{\mathrm{b}}$ & $6.78 \pm 4.85^{\mathrm{ab}}$ & $6.42 \pm 4.77^{\mathrm{b}}$ & $5.56 \pm 3.82^{\mathrm{b}}$ & $5.14 \pm 3.11^{\mathrm{b}}$ \\
& $1.5 \%$ & $6.87 \pm 3.67^{\mathrm{ab}}$ & $5.88 \pm 3.22^{\mathrm{bc}}$ & $4.76 \pm 2.95^{\mathrm{c}}$ & $4.17 \pm 2.83^{\mathrm{b}}$ & $3.75 \pm 1.88^{\mathrm{b}}$ \\
Lemongrass & $0.5 \%$ & $8.78 \pm 6.16^{\mathrm{a}}$ & $8.24 \pm 5.55^{\mathrm{a}}$ & $7.81 \pm 5.05^{\mathrm{b}}$ & $7.41 \pm 4.85^{\mathrm{b}}$ & $6.57 \pm 4.23^{\mathrm{b}}$ \\
oil & $1 \%$ & $7.92 \pm 5.88^{\mathrm{a}}$ & $7.29 \pm 4.88^{\mathrm{a}}$ & $6.75 \pm 3.77^{\mathrm{b}}$ & $6.23 \pm 3.55^{\mathrm{b}}$ & $5.81 \pm 3.00^{\mathrm{b}}$ \\
& $1.5 \%$ & $7.22 \pm 4.01^{\mathrm{b}}$ & $6.91 \pm 3.78^{\mathrm{ab}}$ & $6.19 \pm 3.56^{\mathrm{b}}$ & $5.79 \pm 3.22^{\mathrm{b}}$ & $4.34 \pm 2.89^{\mathrm{b}}$ \\
\hline
\end{tabular}

Initial load of $\mathrm{MRSA}=10.28 \pm 8.88 \log \mathrm{CFU} / \mathrm{g}$. The values represent mean $\pm \mathrm{SD}$ of three experiments. Means within a column followed by different letters are significantly different $(P<0.05)$. 
Table (3): Reduction \% of MRSA count artificially inoculated into treated minced beef samples.

\begin{tabular}{lllllll}
\hline Groups & Oil concentration & zero & $1^{\text {st }}$ day & $2^{\text {nd }}$ day & $3^{\text {rd }}$ day & $4^{\text {th }}$ day \\
\cline { 2 - 6 } Cinnamon oil & $0.5 \%$ & 19.55 & 25.58 & 34.14 & 42.41 & 55.47 \\
& $1 \%$ & 28.69 & 37.55 & 53.29 & 53.99 & 61.38 \\
\multirow{3}{*}{ Thyme oil } & $1.5 \%$ & 36.28 & 51.58 & 62.23 & 71.3 & 73.92 \\
& $0.5 \%$ & 15.56 & 19.10 & 23.83 & 35.51 & 39.49 \\
\multirow{5}{*}{ Lemongrass oil } & $1 \%$ & 23.83 & 34.04 & 37.55 & 45.91 & 50.00 \\
& $1.5 \%$ & 33.17 & 42.80 & 53.69 & 59.43 & 63.52 \\
& $1.5 \%$ & 13.72 & 19.85 & 24.03 & 27.92 & 34.34 \\
& $1 \%$ & 22.95 & 22.96 & 34.34 & 39.40 & 43.48 \\
& & 22.96 & 32.78 & 39.79 & 43.77 & 57.79 \\
\hline
\end{tabular}

\section{DISCUSSION}

This study was initiated to investigate the antibacterial activity of some essential oils against MRSA strains to determine their potential as candidates for use as antibiotics against MRSA bacterium by potential application in the food for the control of pathogenic bacteria. Sensory evaluation is an easy, quick and efficient method for getting idea about the quality of the product and its overall acceptance, sensory method was used to assess the degree of freshness based on organoleptic characteristics such as color, odor, texture and overall acceptability of the product (Haq et al., 2013).

It is obvious from results obtained above that the sensory properties of different treated minced beef samples during cold storage $\left(4^{\circ} \mathrm{C}\right)$ were enhanced by increasing the concentrations of oils compared to the untreated (control) samples at zero, $1^{\text {st }}, 2^{\text {nd }}, 3^{\text {rd }}$ and $4^{\text {th }}$ day of the storage period. Generally, samples containing 1.5\% Cinnamon oil, Thyme oil and lemon grass oil respectively demonstrated the highest enhancement of sensory attributes. The direct addition of essential oils to food may alter the sensory characteristics of food (Seydim and Sarikus, 2006). Nearly similar results were obtained by Reham (2013); Salem et al. (2010) \& Abd El Fattah (2016).

The obtained results were referred to that the three essential oils (Cinnamon oil, Thyme oil and Lemongrass oil) have an antimicrobial activity against Methicillin Resistant Staphylococcus aureus (MRSA) as follow order, Cinnamon oil $>$ Thyme oil $>$ Lemongrass oil. These results come in accordance with that obtained by Fisher and Phillips (2006) who said that among the greater variety of essential oils lemongrass, thyme and cinnamon oils have gained greater acceptance among food technologists due to their better sensory evaluation and antimicrobial properties \& Sue et al. (2008) who mentioned that essential oils have an inhibitory activity against MRSA strains, specially cinnamon, thyme and lemongrass oils which having the highest level of inhibition \& Salem et al. (2010) who said that the garlic, thyme and lemongrass oils can be used as natural preservatives with both antimicrobial and antioxidant activities against food borne pathogens and spoilage organisms, and therefore may be useful in maintaining the meat quality, extending shelf life of meat products, preventing economic loss and providing the consumer with food containing natural additives, which might be seen more healthful than those of synthetic origin. They investigated the antibacterial effect of thyme oil and lemongrass oil in refrigerated minced beef, they noticed that the examined essential oils had considerable effectiveness in decreasing APC, Enterobacteriacea count, coliform count and Staphylococci count, also, their results indicated that the bacterial counts decrease as the concentration of the oil increases since the concentration $1.5 \%$ gives the best effectiveness \& Sharma; et al. (2012) who revealed that essential oils showed higher effectiveness inhibiting MRSA growth than vancomycin which is the currently used standard for treatment, specially wintergreen, cinnamon, thyme and lemongrass oils \& Reham (2013) who said that the essential oils may be selected for use as potential food bio-preservatives and antimicrobials in minced meat and other foods, Moreover the examined essential oils (Cinnamon oil $>$ Clove oil $>$ Rosemary oil) are more active against Gram positive (S. aureus) than Gram negative bacteria (E. coli) \& Plant and Stephens (2015) who concluded that Lemongrass, Thyme, cinnamon, Clove and oregano oils were found to be the most potent relative to the other Essential oils, and Abd El Fattah (2016) who mentioned that there was an observed growth inhibition of $S$. aureus in minced beef samples treated with different concentrations $(0.5 \%, 1 \%, 1.5 \%)$ of thyme, clove and garlic essential oils, in the following order: 
thyme $>$ clove $>$ garlic oils. Their antibacterial activity increases when increasing their concentration. Therefore, these essential oils may be selected for use as potential food biopreservatives and anti $S$. aureus agents in minced meat.

So the essential oils result in immediate reduction of bacterial population and might be more effective against food borne pathogens and spoilage bacteria when applied directly on foods ready to be used (Seydim and Sarikus, 2006). But in order to achieve effective antimicrobial activity in direct food applications, high concentrations of essential oils are generally needed. It has been recently shown that antimicrobial activity of oregano and thyme essential oils was greater at acidic $\mathrm{PH}$ values and high concentrations of protein with a moderate level of simple sugars (Gutierrez et al., 2009). With the increase of bacterial resistance to antibiotics, there is considerable interest in investigating the antimicrobial effects of essential oils against a range of bacteria, to develop other classes of natural antimicrobials useful for infection control or for the preservation of food. Thus essential oils are promising natural antimicrobial agents with potential application in the food or pharmaceutical industries for the control of pathogenic bacteria (Rahman and Kang, 2009).

Essential oils of plants are of growing interest both in the industry and scientific research because of their antibacterial antiviral, antifungal, antioxidant, anti-inflammatory and insecticidal properties (Kordali et al., 2005; Mourey and Canillac, 2002). Cinnamon oil was reported to consist of many components such as cinnamaldehyde, eugenol, and linalool. Cinnamaldehyde was the predominant active compound found in cinnamon oil. Cinnamaldehyde leads to inhibition of $\mathrm{N}-$ 3- oxohexanoylLhomoserine lactone (3- oxo-C6-HSL) and AI-2 and has the potential to affect bacterial QS regulated processes (Niu et al., 2006). It has also been shown that, eugenol limits the growth of microorganisms by inhibiting the production of certain enzymes needed for growth (Parasa et al., 2012).

Thyme oil is commonly used in foods mainly for its flavor and aroma. Also thymol which is found in thyme oil, has been commercially available as part of mouth wash for more than hundred years. Besides, it is active against E. coli and $S$. aureus and spoilage flora in meat products, completely stops the growth of fungi at low concentrations and inhibits the aflatoxin production, so it has a role as pharmaceutical and preservative (Soliman and badeaa, 2002).
Lemongrass is a rich source of citral, which is used in perfumery and pharmaceutical industries, and bioactive compounds (flavonides and vitamin C). The natural flavonoids are also attracting more and more attention not only due to their antioxidant properties, but as anti-carcinogenic and antiinflammatory agents because of their lipid antiperoxidation effects (Martin et al., 2002). Also Lemongrass oil is composed of three main components, the alpha and beta-citral components which elicit antibacterial action on Gram-positive and Gram-negative organisms, while the third component is mycrene which provided enhanced activities when mixed with either of the two main previously identified components (Onawunmi et al., 1984).

The damage of bacterial cell membrane is considered to be the main mode of antibacterial action of essential oils by their effect on morphology, structure, function, modification in the transport of nutrients, membrane disruption and extensive leakages from the bacterial cells leading to cell death (Cox et al., 2000; Moreira et al., 2005; Santiesteban-Lopez et al., 2007; Schelz et al., 2010; Sikkema et al., 1995; Ultee et al., 2002) (Bajpai et al., 2012). Some authors said that considering the large number of different groups of chemical compounds present in essential oils, it is most likely that their antibacterial activity is not attributable to one specific mechanism but that several targets in the cell (Carson et al., 2002). Other authors investigated the antibacterial activity of the essential oils on various microorganisms and found that they are effective against almost all bacterial species, however the mechanism of the antibacterial activity of essential oils is still not entirely cleared (Carson et al., 2002).

The antibacterial activity of essential oils not only depend on chemical characteristics of essential oils, but also on type of bacteria. Essential oils more effective against Gram positive bacteria than Gram negative bacteria (Hyldgaard et al., 2012). Essential oils were found to be more effective against Gram positive bacteria, including MRSA and MSSA, than Gram negative bacteria. This evidence suggests the more effective permeability barrier Gram-negative bacteria possess may better restrict the penetration of amphipathic compounds than Gram positive microbes (Fisher and Phillips, 2009; Jolly and Menon, 2015; Mangena and Muyima, 1999; SmithPalmer et al., 1999).

Many in vitro studies report a high efficacy of essential oils against food-borne pathogens and spoilage bacteria Elgayyar et al. (2001); Seydim and Sarikus (2006) \& Yasin and Abou-Taleb (2007). 
In conclusion, it is suggested that Cinnamon, thyme and lemongrass oils can be used as natural meat preservatives with antimicrobial activities against food borne pathogens, and therefore may be useful in maintaining the meat quality, extending shelf- life of meat products, preventing economic loss and providing the consumer with food containing natural additives, which might be seen more healthful than those of synthetic origin. Further research is necessary to explore the efficiency and palatability of suitable concentrations of natural oils in meat industry. This may represent a valuable weapon against MRSA in food.

\section{REFERENCES}

Abd El Fattah, A.H., 2016. Control of some pathogenic microorganisms in minced meat using essential oils. M.V.Sc. thesis, Meat Hygiene, Fac. Vet., Benha Univ.

Bajpai, V.K., Back, K.H., Kang, S.C., 2012. Control of Salmonella in foods by using essential oils: A review. Food Research International 45, 722734.

Burt, S., 2004. Essential oils: their antibacterial properties and potential applications in foods. A review. Int. J. Food Microbiol. 94, 223 - 253.

Carson, C.F., Mee, B.J., Riley, T.V., 2002. mechanism of action of Tea Tree oil on Staphylococcus aureus determined by time-kill, leakage and salt tolerance assays and electron microscopy. Antimicrobial agents and chemotherapy 46, 1914-1920.

Cox, S.D., Mann, C.M., Markham, J.L., Gustafson, J.E., Warmington, J.R., Wyllie, S.G., 2000. The mode of antimicrobial action of the essential oil of tee tree oil J. App. Microb. 8, 170-175.

Elgayyar, M., Draughon, F.A., Golden, D.A., Mount, J.R., 2001. Antimicrobial activity of essential oils from plants against selected pathogenic and saprophytic microorganisms. J. Food Protection 64, 1019-1024.

Feldman, D., Ganon, J., Haffman, R., Simpson, J., 2003. The solution for data analysis and presentation graphics. $2^{\text {nd }}$ Ed., Abacus Lancripts, Inc., Berkeley, USA.

Fisher, K., Phillips, C., 2006. The effect of lemon, orange and bergamot essential oils and their components on microorganisms. J. Appl. Microbiol. 101, 1232-1240.

Fisher, K., Phillips, C., 2009. The mechanism of action of a citrus oil blend against Enterococcus faecium and Enterococcus faecalis. J. Appl. Microbiol. 106, 1343-1349.

Gutierrez, J., Barry-Ryan, C., Bourke, P., 2009. Antimicrobial activity of plant essential oils using food model media: Efficacy, synergistic potential and interactions with food components. Food Microbiology5 26, 142-150.
Haq, M., Dutta, P.L., Sultana, N., Rahman, A., 2013. Production and quality assessment of fish burger from the grass carp, Ctenopharyngodon idella (Cuvier and Valenciennes, 1844). Journal of Fisheries 1, 42-47.

Heuvelink, A.E., Zwarthruis-Nahuis, J.T., Wit, B., Huijsdens, X.W., De Neeling, A.G., 2009. Prevalence of methicillin resistant staphylococcus aureus in meat. Int. J. Food Microbiol. 31, 52-56.

Hyldgaard, M., Mygind, T., Meyer, R.L., 2012. Essential oils in food preservation: mode of action, synergies and interactions with food matrix components. Front Microbiology 3, 12.

Jolly, D., Menon, V., 2015. Antibacterial effect of garlic and ginger extracts on E. coli and Listeria monocytogenes. International Journal of Applied and Pure Science and Agriculture 1, 111-118.

Kordali, S., Kotan, R., Mavi, A., Cakir, A., Ala, A., Yildirim, A., 2005. Determination of the chemical composition and antioxidant activity of the essential oil of Artemisia dracunculus and of the antifungal and antibacterial activities of Turkish Artemisia absinthium, A. dracunculus, Artemisia santonicum and Artmisia spicigera essential oils. J. Agric. Food Chem. 53, 94529458.

Lambert, A.D., Smith, J.P., Dodds, k.L., 1991. Shelf-life extension and microbiological safety of fresh meat. A review. Food Microbiol. 9, 267-297.

Mangena, T., Muyima, N.Y., 1999. Comparative evaluation of the antimicrobial activities of essential oils of Artemisia afra, Pteronia incana and, 106(4):1343 Rosemarinus officinalis bacteria and yeast strains. Lett. Appl. Microbiol. 28, 291-296.

Martin, F.R., Frutos, M.J., Pérez - Alvarez, J.A., Martinez - Sánchez, F., Tel Rio, J.A., 2002. Flavonoids as neutraceutical: structural related antioxidant properties and their role on ascorbic acid preservation. In: Atta- Ur- Rahman (Ed.). Studies in natural products chemistry $26,324-$ 389.

Moreira, M.R., Ponce, A.G., De Valle, C.E., Roura, S.I., 2005. Inhibitory parameters of essential oils to reduce a foodborne pathogen. LebensmittelWissenschaft und-Technology-LWT, 38: 565570.

Mourey, A., Canillac, N., 2002. Anti-Listeria monocytogenes activity of essential oils components of conifers. Food control 13, 289292.

Niu, C., Afre, S., Gilbert, E.S., 2006. Sub inhibitory concentrations of Cinnamaldehyde interfere with quorum sensing. Lett. Appl. Microbiol. 43, 489494.

Olaoye, O.A., Onilude, A.A., 2010. Investigation on potential use of biological agents in the extension of fresh beef in Nigeria. World J. Microbiol. And Biotechnol. 26, 1445-1454.

Onawunmi, G.O., Yisak, W.A., Ogunlan, E.O., 1984. Antibacterial constituents in the essential oil of 
Cymbopogon citratus. Ethnopharmacol J. 12, 279- 286.

Parasa, L.S., Tumati, S.R., Prasad, C., Kumar, L.C.A., 2012. In vitro antibacterial activity of culinary spices aniseed, star anise and cinnamon against bacterial pathogens of fish. Int. J. Pharmacy and Pharmaceutical Sciences 4, 667-670.

Patsias, A., Chouliara, I., Badeka, A., Savvaidis, I.N., Kontominas, M.G., 2006. Shelf life of chilled precooked chicken product stored in air and under modified atmospheres: microbiological, chemical, sensory attributes. Food Microbial 23, 423-429.

Pearson, M.A., Tauber, W.F., 1984. processed meet. 2nd Ed., pp.: 93.AVI pub. Com., Inc. west port, Connection, pp.: 93.

Pesavento, G., Ducci, B., Comodo, N., Nostro, A.L., 2007. Antimicrobial resistance profile of S. aureus isolates from raw meat: a research for MRSA. Food Control 18, 196-200.

Plant, J., Stephens, 2015. Evaluation of the antibacterial activity of a sizable set of essential oils. Med Aromat plant 4, 185.

Rahman, A., Kang, S., 2009. Invitro control of food borne and food spoilage bacteria by essential oil and ethanol extracts of Lonicera Japonica Thum. Food Chemistry 116, 670-675.

Reham, A.A., 2013. Screening of antibacterial activity of Cinnamon, Clove and Rosemary essential oils against common food borne pathogens in minced beef meat. Benha Veterinary Medical J. 25, 1511642.

Salem, A.M., Amin, R.A., Gehan, S., 2010. Studies on Antimicrobial and Antioxidant Efficiency of some Essential Oils in Minced beef. J. American Science 6, 691-700.

Santiesteban-Lopez, A., Palou, E., Lopz-Malo, A., 2007. Susceptibility of food borne bacteria to binary combinations of antimicrobials at selected a (w) and pH. J. Appl. Microbiol. 102, 486-497.

Schelz, Z., Hohmann, J., Joseph Molnar, J., 2010. Recent advances in research of antimicrobial effects of essential oils and plant derived compounds on bacteria. Ethon medicine: A source of Complementary Therapeutics 37, 179201.
Seydim, A.C., Sarikus, G., 2006. Antimicrobial activity of whey protein based edible films incorporated with oregano, rosemary and garlic essential oils. Food Res. Int. 39, 639-644.

Sharma;, P., James, P., Mack, Rojtman, A., 2012. Ten highly eefective essential oils inhibit growth of Methicillin Resistant Staphylococcus aureus (MRSA) and Methicillin sensitive Staphylococcus aureus (MSSA). Int. J. of Pharmacy and Pharmaceutical science 5, 9751491.

Sikkema, J., De Bont, J.A.M., Poolman, B., 1995. Mechanisms of membrane toxicity of hydrocarbons. Microbiological Reviews 59, 201222.

Smith-Palmer, A., Stewart, J., Fyfe, L., 1999. Antimicrobial properties of plant essential oils and essences against five important food borne pathogens. Letters in Applied Microbiology 29, 118-124.

Soliman, K.M., badeaa, R.I., 2002. effects of oil extracted from some medicinal plants on different mycotoxigenic fungi. Food and Chem. Toxicol. 40, 1669-1675.

Stewart, C.M., Cole, M.B., Schaffner, D.W., 2003. Managing the risk of staphylococcal food poisoning from cream filled backed goods to meet a food safety objective. J. Food Protect 66, 1310-1325.

Sue, C., Gray, Y., Craig, O., Karen, N., 2008. Inhibition of Methicillin resistant Staphylococcus aureus (MRSA) by essential oils. Flavor Fragr. J. 23, 444-449.

Threlfall, E.J., Ward, L.R., Frost, J.A., Willshaw, G.A., 2000. The emergence and spread of antibiotic resistance in food borne bacteria. Int. J. Food Microbiol. 62, 1-5.

Ultee, A., Bennink, M.H.J., Moezelaar, R., 2002. The phenolic hydroxyl group of carvacrol is essential for action against the food borne pathogen Bacillus cereus. Applied and Environmental Microbiology 68, 1561-1568.

Yasin, N.M.N., Abou-Taleb, M., 2007. Antioxidant and antimicrobial effects of Marjoram and thyme in coated refrigerated semi fried mull et fish fillets. World J. Dairy \& Food Sci. 2, 1-9. 